\title{
Comparison of the effects of a high- and normal-casein breakfast on satiety, 'satiety' hormones, plasma amino acids and subsequent energy intake
}

\author{
Margriet A. B. Veldhorst ${ }^{1,2} *$, Arie G. Nieuwenhuizen ${ }^{1,2}$, Ananda Hochstenbach-Waelen ${ }^{1,2}$,
} Klaas R. Westerterp ${ }^{1,2}$, Marielle P. K. J. Engelen ${ }^{3}$, Robert-Jan M. Brummer ${ }^{2}$, Nicolaas E. P. Deutz ${ }^{2,3}$ and Margriet S. Westerterp-Plantenga ${ }^{1,2}$

${ }^{1}$ Department of Human Biology, Nutrition and Toxicology Research Institute Maastricht (NUTRIM), Maastricht University, PO Box 616, Maastricht 6200 MD, The Netherlands

${ }^{2}$ Top Institute Food and Nutrition, PO Box 557, Wageningen 6700 AN, The Netherlands

${ }^{3}$ Department of Surgery, Nutrition and Toxicology Research Institute Maastricht (NUTRIM), Maastricht University, PO Box 616, Maastricht 6200 MD, The Netherlands

(Received 13 November 2007 - Revised 12 March 2008 - Accepted 24 April 2008 - First published online 18 July 2008

The present study compared the effects of a high- and normal-casein-protein breakfast on satiety, 'satiety' hormones, plasma amino acid responses and subsequent energy intake. Twenty-five healthy subjects (BMI 23.9 (SEM 0.3 ) $\mathrm{kg} / \mathrm{m}^{2}$; age 22 (SEM 1) years) received a subject-specific standardised breakfast ( $20 \%$ of daily energy requirements): a custard with casein as the single protein source with either 10, 55 and 35 (normal-casein breakfast) or 25, 55 and 20 (high-casein breakfast) \% of energy (En\%) from protein, carbohydrate and fat respectively in a randomised, singleblind design. Appetite profile (visual analogue scale; VAS), plasma glucose, insulin, glucagon-like peptide 1, ghrelin and amino acid concentrations were determined for $4 \mathrm{~h}$; here the sensitive moment in time for lunch was determined. Subjects came for a second set of experiments and received the same custards for breakfast, and an ad libitum lunch was offered at $180 \mathrm{~min}$ after breakfast; energy intake was assessed. There were increased scores of fullness and satiety after the $25 \mathrm{En} \%$ casein-custard compared with the 10 En\% casein-custard, particularly at $180 \mathrm{~min}$ (26 (SEM 4) v. 11 (SEM 5) mm VAS; $P<0.01$ ) and $240 \mathrm{~min}$ (13 (SEM 5) $v$. -1 (SEM 5) mm VAS; $P<0 \cdot 01$ ). This coincided with prolonged elevated plasma amino acid concentrations; total amino acids and branched-chain amino acids were higher after the 25 En\% casein-custard compared with the $10 \mathrm{En} \%$ casein-custard at 180 and $240 \mathrm{~min}(P<0 \cdot 001)$. There was no difference in energy intake (3080 (SEM 229) $v$. 3133 (SEM 226) $\mathrm{kJ}$ for $25 \mathrm{En} \%$ and $10 \mathrm{En} \%$ respectively; NS) from the ad libitum lunch. In conclusion, a breakfast with $25 \%$ of energy from casein is rated as being more satiating than a breakfast with $10 \%$ of energy from casein at 3 and $4 \mathrm{~h}$ after breakfast, coinciding with prolonged elevated concentrations of plasma amino acids, but does not reduce subsequent energy intake.

Satiety: Energy intake: Casein protein: Glucagon-like peptide 1: Ghrelin: Protein kinetics

The increasing incidence of obesity is considered as a major health problem due to its co-morbidity of a number of diseases, including type 2 diabetes mellitus, CVD, and certain types of cancer ${ }^{(1,2)}$. Obesity is the result of a positive energy balance due to energy intake exceeding energy expenditure. In the system of body-weight regulation several pathways are involved and therefore weight management requires a multi-factorial approach ${ }^{(3)}$. Recent findings suggest that a relatively elevated protein intake seems to play a role during weight loss as well as during weight maintenance thereafter ${ }^{(4-7)}$. In addition to the protein-induced satiety that has been shown after a high-protein diet, protein-induced satiety has also been shown after a single meal ${ }^{(8-10)}$. Several studies on different types of protein affecting satiety have been executed ${ }^{(11-16)}$. The question remains, however, whether the larger satiating effects of high-protein meals hold for each specific type of protein.
Casein is a part of milk protein; it comprises $80 \%$ of the protein content of bovine milk ${ }^{(17)}$. Casein is considered as a 'slow' protein because it coagulates in the stomach and delays gastric emptying ${ }^{(18)}$. The slower digestion rate of casein results in smaller but prolonged increased postprandial plasma amino acid levels ${ }^{(18,19)}$. If the extent of postprandial increase in circulating amino acids influences satiety, as was hypothesised by the amino static theory of Mellinkoff et al. ${ }^{(20)}$, consumption of different levels of casein-protein in a single meal should result in differences in subsequent satiety. We investigated possible differences in satiety ratings between a high- and a normal-casein-protein concentration and the mechanisms accompanying those differences. Casein was offered in a breakfast consisting of $20 \%$ of the subjectspecific daily energy requirements, with amounts of casein that represent the highest allowed protein intake per d, i.e. $25 \%$ of energy $(\mathrm{En} \%)$ from protein $v$. the lowest (normal) 
protein intake per $\mathrm{d}, 10 \%$ of energy from $\operatorname{protein}^{(21)}$. Protein was exchanged with fat; carbohydrate content was kept constant at a level of $55 \mathrm{En} \%$ because of its effects on protein metabolism ${ }^{(22)}$, resulting in a comparison of a high-proteinlow-fat breakfast with a normal-protein-normal-fat breakfast with casein as the single protein type.

The aim of the present study was to compare the effects of a high $v$. a normal amount of casein-protein-containing breakfast on plasma amino acid concentrations, appetite profile, such as ratings of hunger, satiety, fullness, and desire to eat, plasma glucose, and possibly related plasma hormone levels of insulin, glucagon-like peptide 1 (GLP-1), and ghrelin and subsequent energy intake. In order to determine the moment in time that may be sensitive to show a possible difference in food intake we first assessed appetite profile ratings and 'satiety' hormones for $4 \mathrm{~h}$ and in the subsequent experiment energy intake was measured at the determined moment in time.

\section{Subjects and methods}

Subjects

Thirty healthy male and female volunteers (BMI $22-30 \mathrm{~kg} / \mathrm{m}^{2}$; age 18-40 years) were recruited by advertisements in local newspapers and on notice boards at the university. They underwent a screening including medical history, measurement of body weight and height and cognitively restrained eating using a Dutch translation of the Three Factor Eating Questionnaire ${ }^{(23,24)}$. Twenty-five subjects (eleven male, fourteen female) were selected on being in good health, non-smokers, non-vegetarian, not cognitively dietary restrained, not using medication apart from oral contraceptives and at most moderate alcohol users. Their mean age was 22 (SEM 1) years, and their body weight was 74.4 (SEM 1.8) $\mathrm{kg}$ (BMI 23.9 (SEM 0.3) $\mathrm{kg} / \mathrm{m}^{2}$ ). A written informed consent was obtained from these participants and the study protocol was approved by the Medical Ethical Committee of the Academic Hospital Maastricht.

\section{Study design}

A randomised, single-blind, within-subject experimental study was performed. All subjects came to the university on two occasions, separated by at least 1 week. On each test day subjects received a subject-specific standardised breakfast and appetite ratings and blood parameters were obtained for $4 \mathrm{~h}$ after breakfast.

After 2 months, when the sensitive moment in time was determined based on appetite profile ratings and concentrations of metabolites, subjects again came to the university on two occasions in a randomised, single-blind design, separated by at least 1 week. On each test day subjects received a subject-specific standardised breakfast and an ad libitum lunch was offered at the previously determined sensitive moment in time.

\section{Breakfast}

Breakfast was offered as a custard with casein (Calcium Caseinate S; DMV International, Veghel, The Netherlands) as the single protein source, with either protein, carbohydrate and fat at 10,55 and $35 \mathrm{En} \%$ (normal protein) or protein, carbohydrate and fat at 25,55 and $20 \mathrm{En} \%$ (high protein). The breakfast contained $20 \%$ of daily energy requirements, calculated as BMR, according to the Harris-Benedict equations, multiplied by an activity index of $1.75^{(25)}$. The mean energy content of the breakfast was 2.52 (SEM 0.07) MJ and the provided breakfasts were completely finished.

The custards were produced by NIZO Food Research b.v. (Ede, The Netherlands) and had tapioca starch (Farinex VA50T; AVEBE, Veendam, The Netherlands and Perfectamyl 3108; AVEBE, Veendam, The Netherlands) and sunflower-seed oil (Reddy; NV Vandemoortele, Roosendaal, The Netherlands) respectively as the carbohydrate and fat sources and were citrus-vanilla (Citrus, Vanilla; J.B. de Lange, Belfeld, The Netherlands) flavoured. Extensive product development and use of a taste panel led to custards that did not differ significantly in colour, taste or viscosity. The amino acid composition of the custards is presented in Table 1.

\section{Lunch}

Lunch consisted of Turkish bread (400 g) with egg salad (400g) with 13,41 and $46 \mathrm{En} \%$ protein, carbohydrate and fat with an energy density of $11.4 \mathrm{~kJ} / \mathrm{g}$. Subjects were instructed to eat till they were comfortably full.

\section{Study protocol}

The protocol started at 08.00 hours after an overnight fast from 22.00 hours. A Venflon catheter was placed in a superficial dorsal vein of the hand for blood sampling. To obtain arterialised venous blood samples the hand was placed in a thermostatically controlled hot box at $60^{\circ} \mathrm{C}$ for $20 \mathrm{~min}$ before the sampling time. A basal blood sample was taken and appetite ratings were scored. After $5 \mathrm{~min}$, a second basal blood sample was obtained and breakfast was offered $(t=0 \mathrm{~min})$ and completed within $20 \mathrm{~min}$. After the first and the last bite, taste perception was scored. Appetite ratings were

Table 1. Amino acid content of the breakfasts given as a custard with either $10 \%$ of energy from casein-protein or $25 \%$ of energy from casein-protein ( $\mathrm{g}$ amino acids $/ 100 \mathrm{~g}$ custard)

\begin{tabular}{lcc}
\hline & Casein $10 \%$ of energy & Casein $25 \%$ of energy \\
\hline Glutamic acid* & 0.447 & 1.127 \\
Aspartic acid $\dagger$ & 0.150 & 0.355 \\
Cysteine & 0.009 & 0.021 \\
Serine & 0.120 & 0.283 \\
Histidine & 0.064 & 0.152 \\
Glycine & 0.040 & 0.094 \\
Threonine & 0.090 & 0.214 \\
Arginine & 0.092 & 0.218 \\
Alanine & 0.064 & 0.150 \\
Tyrosine & 0.120 & 0.283 \\
Valine & 0.141 & 0.333 \\
Methionine & 0.064 & 0.152 \\
Isoleucine & 0.112 & 0.265 \\
Phenylalanine & 0.110 & 0.259 \\
Tryptophan & 0.027 & 0.064 \\
Leucine & 0.204 & 0.483 \\
Lysine & 0.172 & 0.405 \\
Proline & 0.230 & 0.544 \\
\hline
\end{tabular}

* Glutamic acid = glutamine + glutamate

$\dagger$ Aspartic acid $=$ asparagine. 
completed just before breakfast and at 20, 40, 60, 80, 100, 120, 180 and $240 \mathrm{~min}$ after breakfast. Blood samples for urea and amino acid determination were obtained at $-5 \mathrm{~min}$ and subsequently at the same time points as the appetite ratings; blood samples for the determination of glucose, insulin and ghrelin concentrations were obtained before and at 40, 60, 120 and $180 \mathrm{~min}$ after breakfast. Venous blood samples for the determination of GLP-1 concentration were obtained separately before, and at 30, 60, 90, 120 and 180 min after breakfast by means of a Venflon catheter placed in an antecubital vein $^{(26)}$. Subjects were allowed to drink maximally two glasses of water spread over the morning.

In the second set of experiments, the protocol started after an overnight fast from 22.00 hours to 08.30 hours with scoring appetite ratings. Breakfast was offered $(t=0 \mathrm{~min})$ and completed within $20 \mathrm{~min}$. Lunch was offered at the previously determined sensitive moment in time. Subjects were allowed to drink three glasses of water spread over the entire test period.

\section{Measurements}

Appetite profile. To determine the appetite profile, hunger, fullness, satiety, and desire to eat were rated on $100 \mathrm{~mm}$ visual analogue scales (VAS), anchored with 'not at all' and 'extremely' during the test day. VAS are often used to measure subjective appetite sensations and the validity and reproducibility have been shown in several studies ${ }^{(27,28)}$. Subjects were instructed to rate themselves by marking the scale at the point that was most appropriate to their feeling at that time. The distance from this point to the left end of the scale was measured in $\mathrm{mm}$; changes from baseline $(\Delta)$ were calculated by subtracting the baseline score $(-5 \mathrm{~min})$ from the score at a certain time point.

Taste perception. Taste perception profiles of the custards were assessed after the first and the last bite of the breakfast using $100 \mathrm{~mm}$ VAS, anchored with 'not at all' and 'extremely' on the aspects of pleasantness, sweetness, sourness, saltiness, bitterness, savouriness, crispiness, and creaminess.

Energy intake. Lunch was weighed before and after eating and energy intake was calculated by multiplying the difference of the weight of the lunch by the energy value of the lunch as determined by the product labels $(11.4 \mathrm{~kJ} / \mathrm{g})$.

Blood parameters. Blood was distributed into EDTA tubes for glucose, insulin and ghrelin measurement. For GLP-1 measurement blood was collected in EDTA tubes with added dipeptidyl peptidase IV inhibitor. For amino acid and urea determination, blood was collected in lithium heparin tubes. Blood samples were centrifuged at $4^{\circ} \mathrm{C}$ for $10 \mathrm{~min}$ at $3000 \mathrm{rpm}$. Hydrochloric acid and phenylmethylsulfonyl fluoride were added to plasma for active ghrelin determination. For amino acid analysis, $250 \mu \mathrm{l}$ plasma was deproteinised by mixing it with $20 \mathrm{mg}$ dry sulfosalicylic acid. For analysis of urea, $200 \mu \mathrm{l}$ plasma was deproteinised by mixing it with $20 \mu \mathrm{l}$ of a TCA solution $(500 \mathrm{~g} / \mathrm{l})$. All samples were stored at $-80^{\circ} \mathrm{C}$ until further analysis.

Plasma glucose concentrations were determined using the hexokinase method (Glucose HK 125 kit; ABX Diagnostics, Montpellier, France). Insulin concentrations were measured by RIA (Linco Research Inc., St Charles, MO, USA). Plasma active ghrelin concentrations were measured by ELISA
(Linco Research Inc.). Plasma active GLP-1 samples were analysed using ELISA (EGLP-35K; Linco Research Inc.).

Plasma concentrations of amino acids were determined with the use of a fully automated HPLC (Pharmacia, Woerden, The Netherlands), after precolumn derivatisation with $o$-phthaldialdehyde ${ }^{(29)}$. Plasma urea was analysed spectrophotometrically on a COBAS Mira S (Roche Diagnostica, Hoffman-La Roche, Basel, Switzerland).

\section{Statistical analysis}

Data are presented as mean changes from baseline with their standard errors, unless otherwise indicated ${ }^{(30)}$. The area under the curve (AUC) of changes from baseline over time ( $4 \mathrm{~h}$ for appetite ratings, amino acid and urea concentrations; $3 \mathrm{~h}$ for glucose, insulin, GLP-1 and ghrelin concentrations) was calculated using the trapezoidal method. A repeated-measures ANOVA was carried out to determine possible differences between the high- and normal-protein breakfast. After the second set of experiments, a repeated-measures ANOVA was carried out to determine possible differences in energy intake between the breakfasts. A $P$ value $<0.05$ was regarded as statistically significant. Statistical procedures were performed using StatView 5.0 (SAS Institute Inc., USA, 1998).

\section{Results}

Appetite profile

Baseline ratings for appetite scores were not different among treatments (Table 2). The AUC of fullness ratings was increased after the breakfast with $25 \%$ of energy from casein compared with the breakfast with $10 \%$ of energy from casein $(8522$ (SEM 872) v. 5459 (SEM 974) mm VAS; $P<0.01$; Fig. 1). Fullness ratings also were increased after a breakfast with $25 \mathrm{En} \%$ casein compared with a breakfast with $10 \mathrm{En} \%$ casein at several moments in time including at 180 and $240 \mathrm{~min}$ after breakfast $(P<0.01$ and $P<0.01$; Fig. 1$)$. Satiety ratings were increased after the breakfast with $25 \%$ of energy from casein compared with the breakfast with $10 \%$ of energy from casein at 180 and $240 \mathrm{~min}(P<0.05$ and $P<0.05$; Fig. 1$)$.

Table 2. Baseline values of appetite profile scores ( $\mathrm{mm}$ visual analogue scale; VAS) and glucose, insulin, glucagon-like peptide 1 (GLP-1) and ghrelin concentrations before consumption of a breakfast with either $10 \%$ of energy from casein-protein or $25 \%$ of energy from casein-protein in twenty-five subjects (men and women)*

(Mean values with their standard errors)

\begin{tabular}{|c|c|c|c|c|c|}
\hline & \multicolumn{2}{|c|}{$\begin{array}{c}\text { Casein } 10 \% \\
\text { of energy }\end{array}$} & \multicolumn{2}{|c|}{$\begin{array}{c}\text { Casein } 25 \% \\
\text { of energy }\end{array}$} & \multirow[b]{2}{*}{$P$} \\
\hline & Mean & SEM & Mean & SEM & \\
\hline Satiety (mm VAS) & 25 & 4 & 22 & 4 & 0.38 \\
\hline Fullness (mm VAS) & 24 & 4 & 18 & 3 & 0.13 \\
\hline Hunger (mm VAS) & 62 & 4 & 63 & 4 & 0.94 \\
\hline Desire to eat (mm VAS) & 66 & 4 & 66 & 4 & 0.81 \\
\hline Glucose $(\mathrm{mmol} / \mathrm{l})$ & $5 \cdot 16$ & 0.08 & $5 \cdot 27$ & 0.09 & 0.26 \\
\hline Insulin (mU/l) & $12 \cdot 46$ & 0.57 & $22 \cdot 16$ & $5 \cdot 26$ & 0.08 \\
\hline GLP-1 (pmol/l) & $4 \cdot 20$ & 1.99 & 4.50 & 2.55 & 0.62 \\
\hline Ghrelin (pmol/l) & 9.90 & 1.00 & $9 \cdot 38$ & 1.35 & 0.71 \\
\hline
\end{tabular}

${ }^{*}$ Repeated-measures ANOVA. 

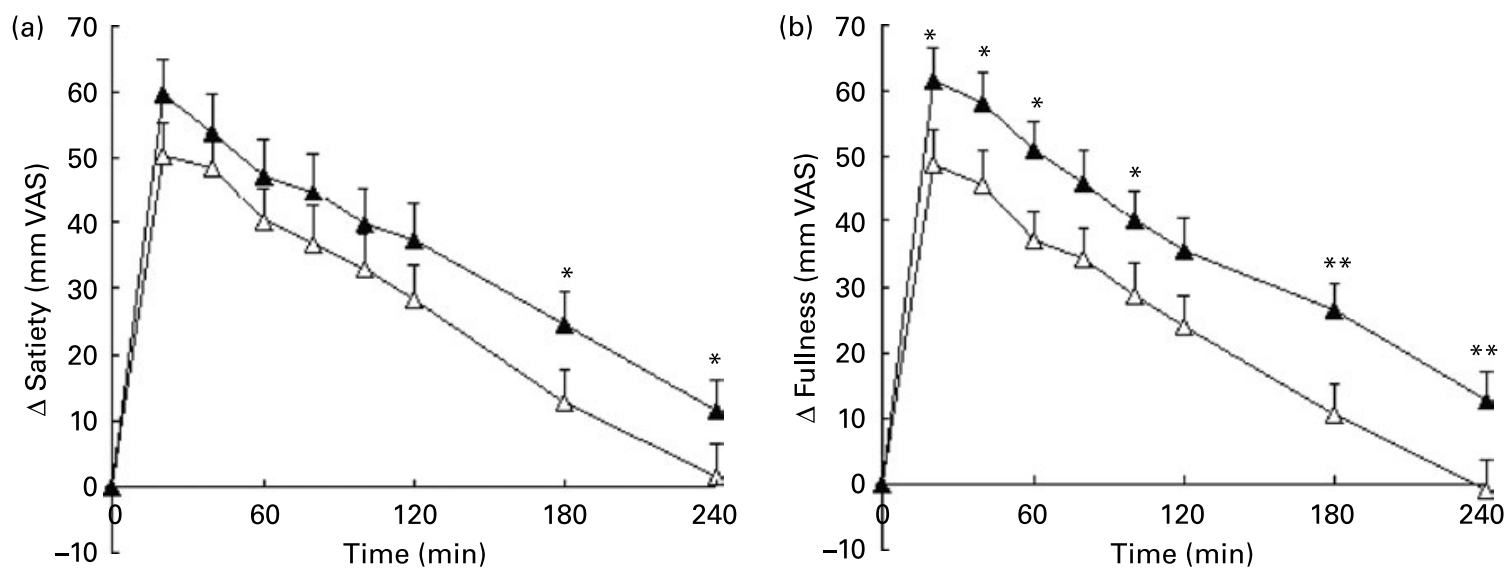

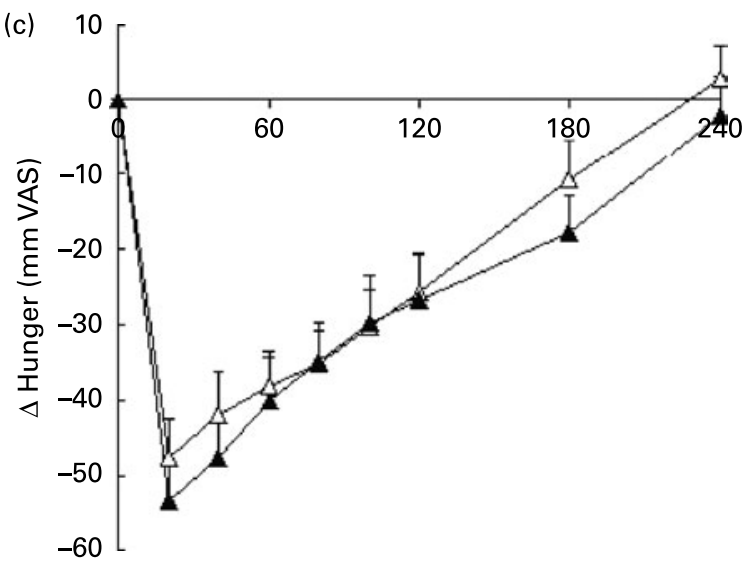

Time $(\min )$

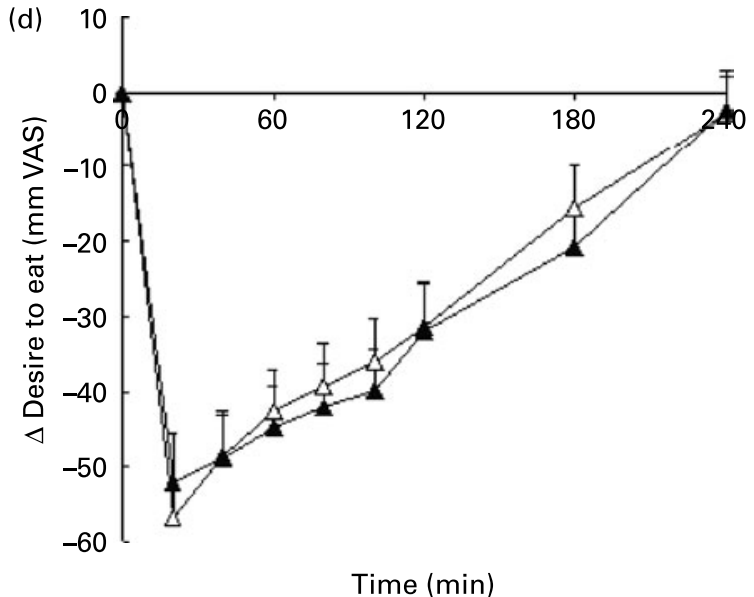

Fig. 1. Changes in satiety (a), fullness (b), hunger (c) and desire to eat (d) (all in mm visual analogue scale; VAS) after a casein-breakfast given as a custard with either $10 \%$ of energy from casein-protein $(\triangle)$ or $25 \%$ of energy from casein-protein $(\Delta)$ expressed as change compared with baseline in twenty-five subjects (men and women). Values are means, with standard errors represented by vertical bars. ${ }^{*} P<0.05,{ }^{\star *} P<0.01$ (repeated-measures ANOVA).

\section{Taste perception}

Ratings of taste perception profiles and of pleasantness of taste of the custards were not different between the breakfast with $25 \%$ of energy from casein and the breakfast with $10 \%$ of energy from protein (Table 3 ).

\section{Glucose}

Baseline plasma glucose concentrations were not different among treatments (Table 2). The glucose response expressed as AUC was increased after the breakfast with $10 \%$ of energy from casein $(123.70($ SEM 14.25$) \mathrm{mmol} / \mathrm{l} \times \mathrm{h})$ compared with the breakfast with $25 \%$ of energy from casein (68.04 (SEM 18.11) $\mathrm{mmol} / \mathrm{l} \times \mathrm{h} ; P<0.05)$. Glucose concentration was increased after the breakfast with $10 \%$ of energy from casein compared with the breakfast with $25 \%$ of energy from casein at 40 and $60 \mathrm{~min}$ after breakfast $(P<0.05$ and $P<0.05$; Fig. 2).

\section{Insulin}

Baseline plasma insulin concentrations were not different among treatments (Table 2). Insulin concentration was increased after the breakfast with $10 \%$ of energy from casein compared with the breakfast with $25 \%$ of energy from casein at $40 \mathrm{~min}$ after breakfast $(P<0 \cdot 05$; Fig. 3$)$.

\section{Glucagon-like peptide 1 and ghrelin}

Baseline plasma GLP-1 and ghrelin concentrations were not different among treatments (Table 2). There were no significant differences in GLP-1 or ghrelin concentrations between a high- and a normal-casein breakfast (data not shown).

\section{Amino acids and urea}

Baseline plasma amino acid and urea concentrations were not different among treatments (Table 4). The AUC of the response of glutamate, asparagine, serine, glutamine, histidine, glycine, threonine, citrulline, arginine, alanine, taurine, $\alpha$-aminobutyric acid, tyrosine, valine, methionine, isoleucine, phenylalanine, tryptophan, leucine, ornithine, lysine, branched-chain amino acids, total amino acids and urea are presented in Table 4; significant differences between treatments are indicated.

Compared with the breakfast with $10 \%$ of energy from casein, almost all amino acids showed a prolonged elevation with a typical pattern after the breakfast with $25 \%$ of energy from casein. Plasma amino acid concentrations rose immediately after breakfast to peak values at $40 \mathrm{~min}$ after 
Table 3. Taste perception profiles and hedonic values on $100 \mathrm{~mm}$ visual analogue scales of the breakfasts given as a custard with either $10 \%$ of energy from casein-protein or $25 \%$ of energy from casein-protein assessed in twenty-five subjects (men and women)*

(Mean values with their standard errors)

\begin{tabular}{lcccccc}
\hline & \multicolumn{2}{c}{$\begin{array}{c}\text { Casein } 10 \% \text { of } \\
\text { energy }\end{array}$} & & \multicolumn{2}{c}{$\begin{array}{c}\text { Casein 25\% of } \\
\text { energy }\end{array}$} \\
\cline { 2 - 3 } \cline { 6 - 7 } & Mean & SEM & & Mean & SEM \\
\hline Pleasantness of taste & 58 & 4 & & 50 & 3 \\
Sweetness & 54 & 6 & & 52 & 5 \\
Saltiness & 9 & 3 & & 11 & 3 \\
Bitterness & 16 & 4 & & 14 & 4 \\
Sourness & 16 & 4 & & 11 & 3 \\
Creaminess & 56 & 6 & & 53 & 5 \\
Crispiness & 2 & 1 & & 3 & 1 \\
Savouriness & 15 & 4 & & 19 & 4 \\
\hline
\end{tabular}

*Repeated-measures ANOVA; no significant differences.

breakfast. Then concentrations slightly decreased, with concentrations increasing again from $80 \mathrm{~min}$ onwards. The second peak levels were reached at $180 \mathrm{~min}$ after breakfast. To illustrate this phenomenon, Fig. 4 presents the plasma amino acid concentrations over time of the branched-chain amino acids and total amino acids. The prolonged elevated concentrations were shown with nearly all amino acids. Total amino acids and branched-chain amino acids as well as glutamate, asparagine, serine, glutamine, histidine, threonine, arginine, alanine, $\alpha$-aminobutyric acid, tyrosine, valine, methionine, isoleucine, phenylalanine, tryptophan, leucine, ornithine and lysine concentrations were increased at 180 and $240 \mathrm{~min}$ after the breakfast with $25 \%$ of energy from casein compared with the breakfast with $10 \%$ of energy from casein $(P<0.05)$

The urea response expressed as AUC was increased after the breakfast with $25 \%$ of energy from casein compared with a breakfast with $10 \%$ of energy from casein $(P<0 \cdot 001$; Table 4$)$.

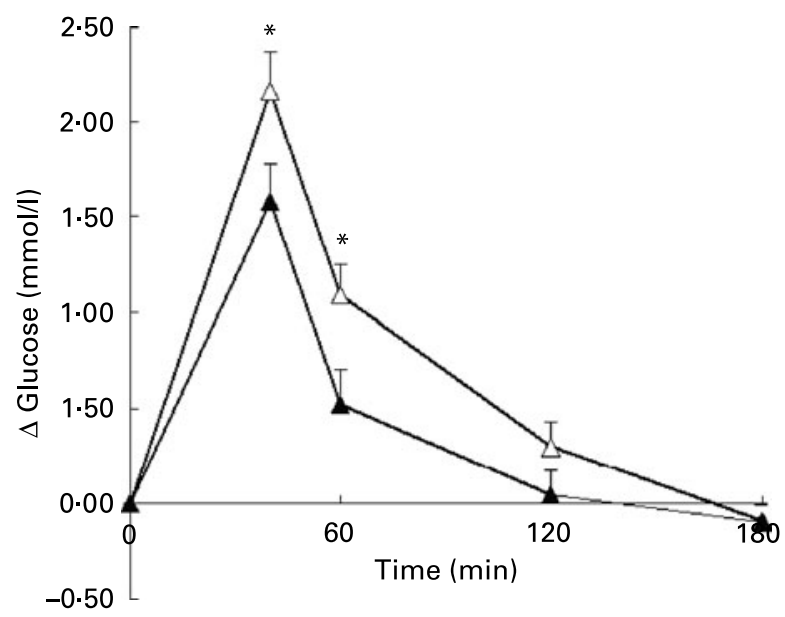

Fig. 2. Changes in glucose concentrations $(\mathrm{mmol} / \mathrm{l})$ after a casein-breakfast given as a custard with either $10 \%$ of energy from casein-protein $(\Delta)$ or $25 \%$ of energy from casein-protein $(\boldsymbol{\Lambda})$ expressed as change compared with baseline in twenty-five subjects (men and women). Values are means, with standard errors represented by vertical bars. ${ }^{*} P<0.05$ (repeated-measures ANOVA).

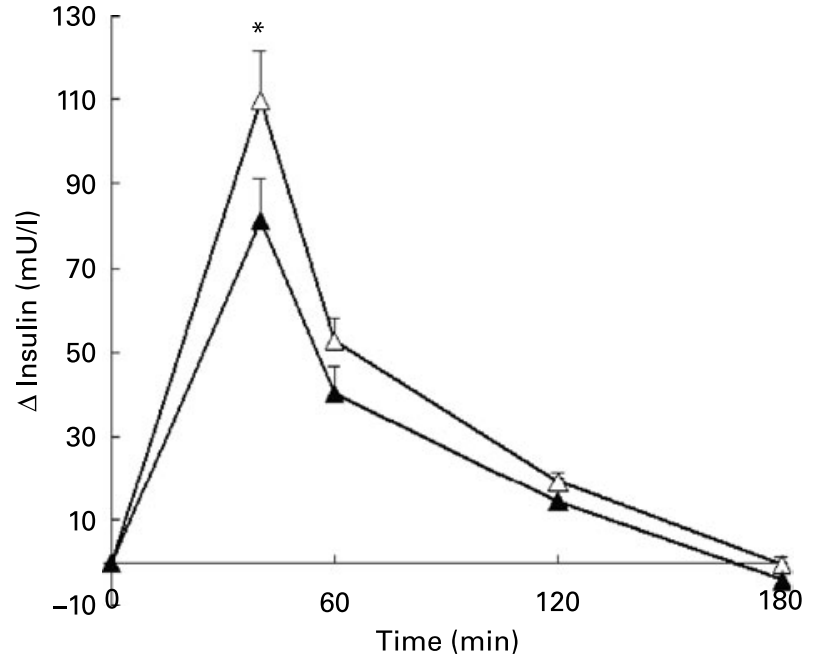

Fig. 3. Changes in insulin concentrations $(\mathrm{mU} / \mathrm{l})$ after a casein-breakfast given as a custard with either $10 \%$ of energy from casein-protein $(\triangle)$ or $25 \%$ of energy from casein-protein $(\boldsymbol{\Lambda})$ expressed as change compared with baseline in twenty-five subjects (men and women). Values are means, with standard errors represented by vertical bars. ${ }^{*} P<0.05$ (repeated-measures ANOVA).

\section{Energy intake}

Based on the results of appetite profile ratings and the concentrations of amino acids the ad libitum lunch was offered at 180 min after breakfast.

Energy intake at lunch was 3133 (SEM 226) and 3080 (SEM 229) $\mathrm{kJ}$ after the breakfasts with $10 \%$ and $25 \%$ of energy from protein, respectively (NS).

\section{Discussion}

Ratings of satiety and fullness were higher after a subjectspecific breakfast consisting of $20 \%$ of total daily energy requirements with casein at a concentration of $25 \%$ of energy from protein compared with the breakfast with $10 \%$ of energy from casein, particularly at 3 and $4 \mathrm{~h}$ after breakfast. Energy intake at lunch was not different after a high- or normal-casein breakfast. Sometimes it is suggested that protein-induced satiety is partly due to specific sensory effects ${ }^{(8)}$. There is, however, hardly any evidence for this suggestion, especially not in the case of amounts of protein of about $30 \mathrm{~g}$ in combination with carbohydrate and fat in a meal. Clearly, most amino acids evoke taste-aversive responses because they have a bitter or sour taste ${ }^{(31)}$. This is why we did not use pure amino acids but applied complete proteins. Nevertheless, to avoid any specific sensory effect, food technology was involved to optimise taste and hedonic value of the breakfasts. The custards were vanilla-lemon flavoured and after being tested by a professional taste panel of NIZO Food Research taste perception and hedonic values again were evaluated by the subjects (see Table 2) and were excluded from affecting appetite profile ratings differently.

The increased satiety after the breakfast with $25 \%$ of energy from casein compared with the breakfast with $10 \%$ of energy from casein coincided with prolonged elevated concentrations of amino acids. Since postprandial amino acid profiles are likely to reflect rates of digestion, absorption and metabolism, the prolonged elevated concentrations indicate a 
Table 4. Baseline values and areas under the curve (AUC) of amino acid ( $\mu \mathrm{mol} / \mathrm{l}$ and $\mu \mathrm{mol} / / \mathrm{l} \times \mathrm{h}$ ) and urea (mmol/l and $\mathrm{mmol} / \mathrm{l} \times \mathrm{h}$ ) responses after a casein-protein breakfast given as a custard with either $10 \%$ of energy from casein-protein or $25 \%$ of energy from casein-protein in twenty-five subjects (men and women)†

(Mean values with their standard errors)

\begin{tabular}{|c|c|c|c|c|c|c|c|c|c|}
\hline & \multicolumn{4}{|c|}{ Casein $10 \%$ of energy } & \multicolumn{4}{|c|}{ Casein $25 \%$ of energy } & \multirow{2}{*}{$P$} \\
\hline & \multicolumn{2}{|c|}{ Baseline } & \multicolumn{2}{|c|}{ AUC } & \multicolumn{2}{|c|}{ Baseline } & \multicolumn{2}{|c|}{ AUC } & \\
\hline Glutamate & 104 & 4 & -102 & 506 & 98 & 4 & 2220 & 454 & *** \\
\hline Asparagine & 58 & 2 & 2717 & 263 & 56 & 1 & 7304 & 428 & *** \\
\hline Serine & 127 & 4 & 3574 & 500 & 128 & 5 & 7943 & 754 & *** \\
\hline Histidine & 94 & 3 & 2069 & 217 & 95 & 3 & 5448 & 453 & *** \\
\hline Glycine & 239 & 11 & -2242 & 438 & 224 & 11 & -476 & 791 & \\
\hline Threonine & 143 & 5 & 4414 & 333 & 138 & 6 & 13370 & 803 & *** \\
\hline Citrulline & 31 & 1 & -938 & 134 & 31 & 1 & -339 & 126 & *** \\
\hline Arginine & 88 & 3 & 1845 & 238 & 86 & 3 & 6638 & 386 & *** \\
\hline Alanine & 316 & 18 & 30021 & 2219 & 288 & 13 & 36568 & 1822 & * \\
\hline Taurine & 34 & 1 & -464 & 117 & 33 & 1 & -72 & 102 & * \\
\hline$\alpha$-Aminobutyric acid & 18 & 1 & 149 & 84 & 19 & 1 & 682 & 97 & *** \\
\hline Methionine & 25 & 1 & 1799 & 212 & 24 & 1 & 5470 & 366 & *** \\
\hline Isoleucine & 64 & 2 & 4624 & 292 & 67 & 2 & 13811 & 605 & *** \\
\hline Phenylalanine & 49 & 1 & 1990 & 154 & 50 & 1 & 5416 & 290 & *** \\
\hline Tryptophan & 49 & 1 & -216 & 144 & 49 & 1 & 1947 & 201 & *** \\
\hline Leucine & 110 & 3 & 7027 & 393 & 117 & 4 & 22578 & 1038 & *** \\
\hline Ornithine & 53 & 2 & 2366 & 284 & 54 & 3 & 4735 & 375 & *** \\
\hline Lysine & 154 & 5 & 13181 & 725 & 170 & 5 & 27251 & 1139 & *** \\
\hline Branched-chain amino acids & 368 & 9 & 19528 & 959 & 375 & 11 & 64963 & 3002 & *** \\
\hline Total amino acids & 2534 & 50 & 84438 & 5316 & 2493 & 51 & 210435 & 10785 & *** \\
\hline Urea & $4 \cdot 10$ & 0.19 & -48 & 14 & $4 \cdot 12$ & 0.16 & 67 & 14 & $\star \star \star *$ \\
\hline
\end{tabular}

${ }^{\star} P<0.05,{ }^{* *} P<0.01,{ }^{* * *} P<0.001$

† Repeated-measures ANOVA.

difference in protein kinetics between the two breakfasts. Previously it has been shown that casein coagulates in the stomach which delays gastric emptying; therefore casein is considered as a 'slow' protein. The higher the casein concentration the slower the release of food into the duodenum $^{(18,19,32)}$. This is reflected by the typical pattern of amino acid concentrations over time. The largest differences in amino acid concentrations between the breakfasts with $25 \%$ and $10 \%$ of energy from casein existed at 3 and $4 \mathrm{~h}$ after breakfast. These prolonged elevated concentrations may have contributed to the increased satiety ratings after the breakfast with $25 \%$ of energy from casein, which is in line with Mellinkoff's amino static theory that states that a larger rise in plasma amino acids increases satiety ${ }^{(20)}$. The increased satiety ratings after the breakfast with $25 \%$ of energy from casein may thus be explained by increased concentrations of amino acids caused by the delayed gastric emptying of casein.

Surprisingly, the insulin concentration was increased after the breakfast with $10 \%$ of energy from casein whereas the glucose response expressed as AUC also was significantly increased after the breakfast with $10 \%$ of energy from casein compared with the breakfast with $25 \%$ of energy from casein whereas the carbohydrate content of the two breakfasts was exactly the same. The slower release of food into the duodenum after the high-casein breakfast also delayed and diminished the rise of glucose and subsequently insulin concentrations in the circulation. Previously, insulin concentrations have been shown not to increase after consumption of a meal with 'slow' proteins in healthy young adults ${ }^{(19)}$.
Protein kinetics, reflected by changes in plasma amino acid concentrations, were different between the high- and normalcasein breakfast. The high-casein breakfast revealed a plasma amino acid pattern that is typical for a 'slow' protein and that was, besides glucose and insulin responses, also reflected by the changes in GLP-1 and ghrelin concentrations. The absence of significant differences in GLP-1 or ghrelin concentrations between the high- and normal-casein breakfasts may be the result of the delayed gastric emptying and thus retarded entrance of food in the intestine followed by a diminished physiological response of GLP-1 secretion and a less pronounced decrease in ghrelin concentration. In summary, the breakfast with $25 \%$ of energy from casein delayed gastric emptying more compared with the breakfast with $10 \%$ of energy from casein resulting in less pronounced changes in insulin, GLP-1 and ghrelin.

In the literature differences in 'satiety' hormone responses between the different macronutrients have been shown ${ }^{(12,13,33,34)}$. In a review by Cummings it is stated that protein intake does not affect ghrelin response particularly ${ }^{(35)}$. For instance, no differences in ghrelin concentrations after a high-protein (30 En\% protein) compared with a normal-protein diet (10En\% protein) were observed, when the high- or normal-protein diet was given during three meals over $1 \mathrm{~d}^{(36)}$. Foster-Schubert, however, reported a stronger suppression of ghrelin by proteins compared with fat or carbohydrates ${ }^{(33)}$, with a test meal extremely high in protein with hardly any of the other macronutrients present. This makes comparisons with less extreme meals, such as in the present study a moderately high-protein meal that is representative for a relatively 

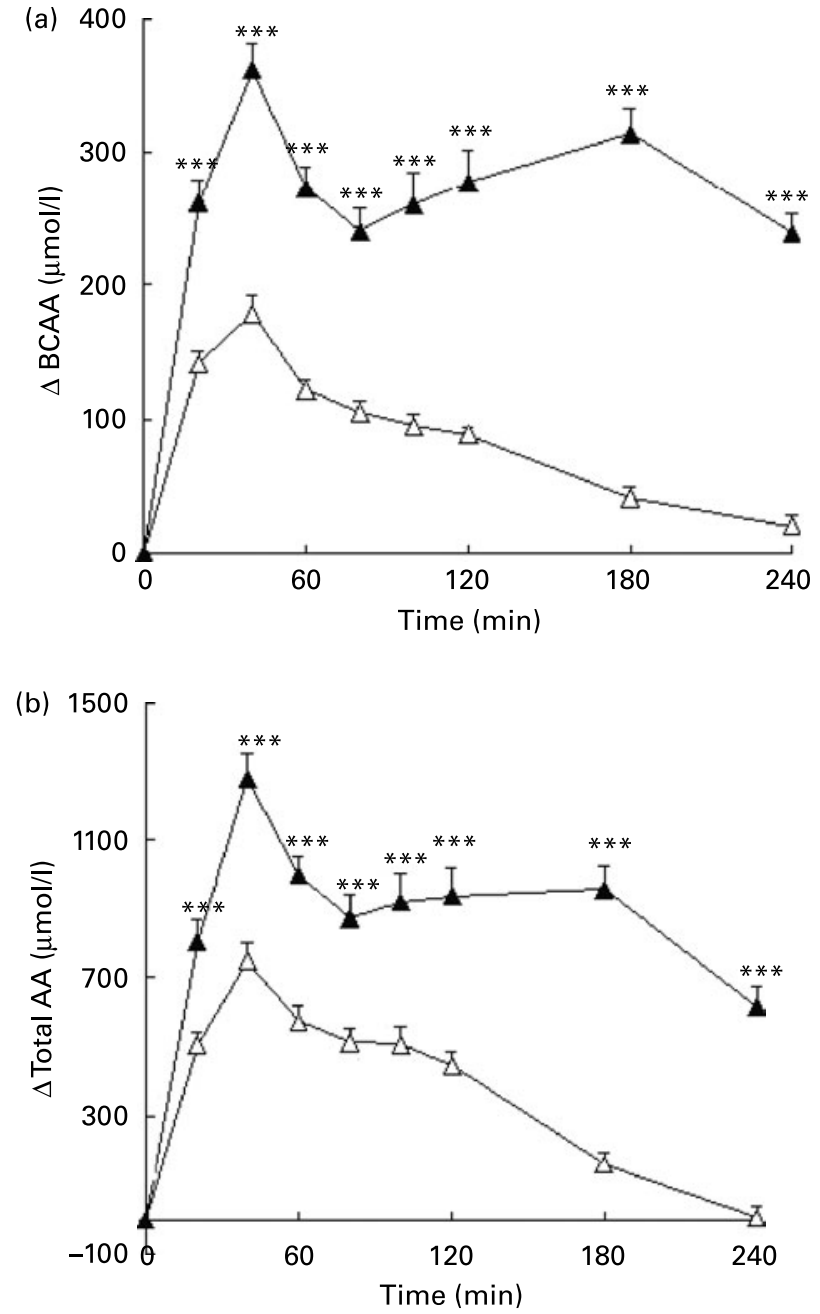

Fig. 4. Changes in plasma branched-chain amino acid (BCAA) concentrations $(\mu \mathrm{mol} / \mathrm{l})(\mathrm{a})$ and plasma total amino acid (total $\mathrm{AA}$ ) concentrations $(\mu \mathrm{mol} / \mathrm{l})(\mathrm{b})$ after a casein-breakfast given as a custard with either $10 \%$ of energy from casein-protein $(\Delta)$ or $25 \%$ of energy from casein-protein $(\boldsymbol{\Lambda})$ expressed as change compared with baseline in twenty-five subjects (men and women). Values are means, with standard errors represented by vertical bars. ${ }^{\star \star \star} P<0.001$ (repeated-measures ANOVA).

high daily protein intake of $25 \%$ of energy from protein with a normal amount of carbohydrates $(55 \mathrm{En} \%)$ and a low amount of fat $(20 \mathrm{En} \%)$, difficult. Other observations showed that different types of protein modified 'satiety' hormone responses differently in some ${ }^{(11,15)}$ but not all studies ${ }^{(14,16)}$. In the present study there were no differences in GLP-1 and ghrelin between two levels of casein-protein, probably due to the fact that casein is a 'slow' protein. This would result in a compensation of the effect of concentration by pace of nutrient-stimulated hormone release.

Despite significantly increased ratings of satiety after the breakfast with $25 \%$ of energy from casein at $3 \mathrm{~h}$ after breakfast, energy intake was similar after the high- and normal-casein breakfast. Apparently the difference in satiety ratings of $12-$ $15 \mathrm{~mm}$ VAS was not large enough to induce a significant effect on food intake. Previously, Diepvens et al. also reported a significant suppressive effect of a preload on appetite ratings whereas there was no effect on ad libitum energy intake $4 \mathrm{~h}$ after the preload. They concluded that the difference in hunger scores may be too small to exert an effect on subsequent energy intake and that timing is of major importance to observe significant effects on food intake (K Diepvens, J Steijns, $\mathrm{P}$ Zuurendonk and MS Westerterp-Plantenga, unpublished results). In the past there have been experiments that showed differences in subsequent energy intake between types of protein offered as a preload without significant differences in appetite ratings ${ }^{(11,37,38)}$. In case subsequent energy intake is affected without pre-prandial indications of appetite profile ratings, it may well be that the combination of the digested food from the previous preload or meal with the new digested food in the gut may evoke uncomfortable feelings that stop further energy intake. Furthermore, differences in timing may explain different results; timing is essential in studying ad libitum energy intake after a preload or a meal as shown by Anderson et al. ${ }^{(37)}$. In accordance with other studies (K Diepvens, J Steijns, P Zuurendonk and MS Westerterp-Plantenga, unpublished results), the present study shows that differences in appetite ratings thus need to be at least larger than $15 \mathrm{~mm}$ VAS in order to have a significant effect on subsequent energy intake. Although the high-casein breakfast was rated as more satiating than the normal-casein breakfast the difference was not large enough to induce a reduction in energy intake.

Urea concentrations were elevated more after the highcasein breakfast compared with the normal-protein breakfast with casein. The high urea concentrations reflect an excess of amino acids and a state of positive protein balance after the high-protein breakfast. Postprandial protein synthesis has high ATP costs ${ }^{(39)}$ and when amino acids are given in excess of protein deposition, amino acid oxidation plays a major role in energy expenditure and protein oxidation ${ }^{(40,41)}$ that previously has been shown to be related to diet-induced thermogenesis and increased satiety ${ }^{(9,42)}$.

This is the first study that investigated acute differences in satiety between two concentrations of casein; previously the satiating properties of casein only have been compared with other protein types ${ }^{(11,14)}$. The present study shows that a breakfast with $25 \%$ of energy from casein is rated as being more satiating than a breakfast with $10 \%$ of energy from casein at 3 and $4 \mathrm{~h}$ after breakfast, coinciding with prolonged elevated concentrations of plasma amino acids, but does not reduce subsequent energy intake.

\section{Acknowledgements}

M. A. B. V., A. G. N., A. H.-W., K. R. W., M. P. K. J. E., R. J. M. B., N. E. P. D. and M. S. W.-P. designed the study. M. A. B. V. and A. H.-W. collected and analysed the data. M. A. B. V. wrote the manuscript and A. G. N., K. R. W., M. P. K. J. E., N. E. P. D. and M. S. W.-P. contributed to interpretation of the data and reviewed the manuscript. The study was executed under supervision of A. G. N., K. R. W. and M. S. W.-P. None of the authors had a personal or financial conflict of interest.

\section{References}

1. Seidell JC (1995) Obesity in Europe. Obes Res 3, Suppl. 2, 89s-93s.

2. Pi-Sunyer FX (1993) Medical hazards of obesity. Ann Intern Med 119, 655-660.

3. Westerterp-Plantenga MS, Luscombe-Marsh N, Lejeune MPGM, Diepvens K, Nieuwenhuizen A, Engelen MPKJ, Deutz NEP, Azzout-Marniche D, Tome D \& Westerterp KR (2006) Dietary 
protein, metabolism, and body-weight regulation: dose-response effects. Int J Obes (Lond) 30, Suppl. 3, S16-S23.

4. Skov AR, Toubro S, Ronn B, Holm L \& Astrup A (1999) Randomized trial on protein vs carbohydrate in ad libitum fat reduced diet for the treatment of obesity. Int $J$ Obes Relat Metab Disord 23, 528-536.

5. Lejeune MPGM, Kovacs EM \& Westerterp-Plantenga MS (2005) Additional protein intake limits weight regain after weight loss in humans. Br J Nutr 93, 281-289.

6. Weigle DS, Breen PA, Matthys CC, Callahan HS, Meeuws KE, Burden VR \& Purnell JQ (2005) A high-protein diet induces sustained reductions in appetite, ad libitum caloric intake, and body weight despite compensatory changes in diurnal plasma leptin and ghrelin concentrations. Am J Clin Nutr 82, 41-48.

7. Clifton PM, Keogh JB \& Noakes M (2008) Long-term effects of a high-protein weight-loss diet. Am J Clin Nutr 87, 23-29.

8. Bertenshaw EJ, Lluch A \& Yeomans MR (2007) Satiating effects of protein but not carbohydrate consumed in a between-meal beverage context. Physiol Behav 83, 211-220.

9. Crovetti R, Porrini M, Santangelo A \& Testolin G (1998) The influence of thermic effect of food on satiety. Eur J Clin Nutr 52, 482-488.

10. Halton TL \& Hu FB (2004) The effects of high protein diets on thermogenesis, satiety and weight loss: a critical review. $J \mathrm{Am}$ Coll Nutr 23, 373-385.

11. Hall WL, Millward DJ, Long SJ \& Morgan LM (2003) Casein and whey exert different effects on plasma amino acid profiles, gastrointestinal hormone secretion and appetite. Br J Nutr 89, 239-248.

12. Bowen J, Noakes M \& Clifton PM (2006) Appetite regulatory hormone responses to various dietary proteins differ by body mass index status despite similar reductions in ad libitum energy intake. J Clin Endocrinol Metab 91, 2913-2919.

13. Bowen J, Noakes M, Trenerry C \& Clifton PM (2006) Energy intake, ghrelin, and cholecystokinin after different carbohydrate and protein preloads in overweight men. J Clin Endocrinol Metab 91, 1477-1483.

14. Lang V, Bellisle F, Oppert JM, Craplet C, Bornet FR, Slama G \& Guy-Grand B (1998) Satiating effect of proteins in healthy subjects: a comparison of egg albumin, casein, gelatin, soy protein, pea protein, and wheat gluten. Am J Clin Nutr 67, 1197-1204.

15. Lang V, Bellisle F, Alamowitch C, Craplet C, Bornet FR, Slama G \& Guy-Grand B (1999) Varying the protein source in mixed meal modifies glucose, insulin and glucagon kinetics in healthy men, has weak effects on subjective satiety and fails to affect food intake. Eur J Clin Nutr 53, 959-965.

16. Uhe AM, Collier GR \& O'Dea K (1992) A comparison of the effects of beef, chicken and fish protein on satiety and amino acid profiles in lean male subjects. J Nutr 122, 467-472.

17. Miller MJ, Witherly SA \& Clark DA (1990) Casein: a milk protein with diverse biologic consequences. Proc Soc Exp Biol Med 195, 143-159.

18. Boirie Y, Dangin M, Gachon P, Vasson MP, Maubois JL \& Beaufrère B (1997) Slow and fast dietary proteins differently modulate postprandial protein accretion. Proc Natl Acad Sci U S A 94, 14930-14935.

19. Dangin M, Boirie Y, Garcia-Rodenas C, Gachon P, Fauquant J, Callier P, Ballèvre O \& Beaufrère B (2001) The digestion rate of protein is an independent regulating factor of postprandial protein retention. Am $J$ Physiol Endocrinol Metab 280, E340-E348.

20. Mellinkoff SM, Frankland M, Boyle D \& Greipel M (1956) Relationship between serum amino acid concentration and fluctuations in appetite. J Appl Physiol 8, 535-538.

21. Spaaij CJ \& Pijls LT (2004) New dietary reference intakes in The Netherlands for energy, proteins, fats and digestible carbohydrates. Eur J Clin Nutr 58, 191-194.
22. Munro HN (1976) Second Boyd Orr Memorial Lecture. Regulation of body protein metabolism in relation to diet. Proc Nutr Soc 35, 297-308.

23. Stunkard AJ \& Messick S (1985) The three-factor eating questionnaire to measure dietary restraint, disinhibition and hunger. J Psychosom Res 29, 71-83.

24. Westerterp-Plantenga MS, Westerterp KR, Rubbens M, Verwegen CR, Richelet JP \& Gardette B (1999) Appetite at "high altitude" [Operation Everest III (Comex-'97)]: a simulated ascent of Mount Everest. J Appl Physiol 87, 391-399.

25. Harris JA \& Benedict FG (1919) A Biometric Study of Basal Metabolism in Man. Washington, DC: Carnegie Institute of Washington.

26. Adam TC \& Westerterp-Plantenga MS (2005) Nutrient-stimulated GLP-1 release in normal-weight men and women. Horm Metab Res 37, 111-117.

27. Stubbs RJ, Hughes DA, Johnstone AM, Rowley E, Reid C, Elia M, Stratton R, Delargy H, King N \& Blundell JE (2000) The use of visual analogue scales to assess motivation to eat in human subjects: a review of their reliability and validity with an evaluation of new hand-held computerized systems for temporal tracking of appetite ratings. $\mathrm{Br} J \mathrm{Nutr} \mathbf{8 4}$, 405-415.

28. Flint A, Raben A, Blundell JE \& Astrup A (2000) Reproducibility, power and validity of visual analogue scales in assessment of appetite sensations in single test meal studies. Int $J$ Obes Relat Metab Disord 24, 38-48.

29. van Eijk HM, Rooyakkers DR \& Deutz NE (1993) Rapid routine determination of amino acids in plasma by high-performance liquid chromatography with a $2-3$ microns Spherisorb ODS II column. J Chromatogr 620, 143-148.

30. Senn S (2006) Cross-over trials in Statistics in Medicine: The first ' 25 ' years. Stat Med 25, 3430-3442.

31. Kirimura J, Shimizi A, Kimizuka A, Ninomiya T \& Katsuya N (1969) The contribution of peptides and amino acids to the taste of foodstuffs. J Agric Food Chem 17, 689-695.

32. Mahé S, Roos N, Benamouzig R, Davin L, Luengo C, Gagnon L, Gaussergès N, Rautureau J \& Tomé D (1996) Gastrojejunal kinetics and the digestion of $\left[{ }^{15} \mathrm{~N}\right] \beta$-lactoglobulin and casein in humans: the influence of the nature and quantity of the protein. Am J Clin Nutr 63, 546-552.

33. Foster-Schubert KE, Overduin J, Prudom CE, Liu J, Callahan HS, Gaylinn BD, Thorner MO \& Cummings DE (2008) Acyl and total ghrelin are suppressed strongly by ingested proteins, weakly by lipids, and biphasically by carbohydrates. J Clin Endocrinol Metab 93, 1971-1979.

34. Erdmann J, Lippl F \& Schusdziarra V (2003) Differential effect of protein and fat on plasma ghrelin levels in man. Regul Pept 116, 101-107.

35. Cummings DE (2006) Ghrelin and the short- and long-term regulation of appetite and body weight. Physiol Behav 89, $71-84$.

36. Lejeune MP, Westerterp KR, Adam TC, Luscombe-Marsh ND \& Westerterp-Plantenga MS (2006) Ghrelin and glucagon-like peptide 1 concentrations, 24-h satiety, and energy and substrate metabolism during a high-protein diet and measured in a respiration chamber. Am J Clin Nutr 83, 89-94.

37. Anderson GH, Tecimer SN, Shah D \& Zafar TA (2004) Protein source, quantity, and time of consumption determine the effect of proteins on short-term food intake in young men. J Nutr 134, 3011-3015.

38. Borzoei S, Neovius M, Barkeling B, Teixeira-Pinto A \& Rossner S (2006) A comparison of effects of fish and beef protein on satiety in normal weight men. Eur J Clin Nutr 60, 897-902.

39. van Milgen J (2002) Modeling biochemical aspects of energy metabolism in mammals. $J$ Nutr 132, 3195-3202. 
40. Pannemans DL, Wagenmakers AJ, Westerterp KR, Schaafsma G \& Halliday D (1998) Effect of protein source and quantity on protein metabolism in elderly women. Am J Clin Nutr $\mathbf{6 8}$ $1228-1235$.

41. Robinson SM, Jaccard C, Persaud C, Jackson AA, Jequier E \& Schutz Y (1990) Protein turnover and thermogenesis in response to high-protein and high-carbohydrate feeding in men. $A m J$ Clin Nutr 52, 72-80.

42. Westerterp-Plantenga MS, Rolland V, Wilson SA \& Westerterp KR (1999) Satiety related to $24 \mathrm{~h}$ diet-induced thermogenesis during high protein/carbohydrate vs high fat diets measured in a respiration chamber. Eur J Clin Nutr 53, 495-502. 